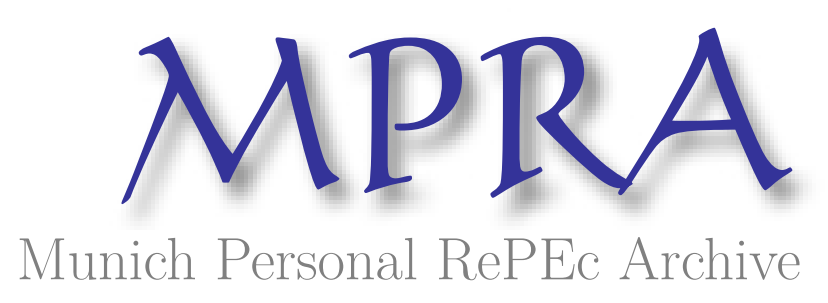

\title{
Urban growth and productivity: the case of Greece
}

Louri, Helen

January 1988

Online at https://mpra.ub.uni-muenchen.de/29934/

MPRA Paper No. 29934, posted 13 Apr 2011 17:33 UTC 


\section{Urban Growth and Productivity: The Case of Greece}

\section{Helen Louri}

Sunmary. The present paper reports an attempt to eatimate the role of arbanioation economies in Greek lndwotry. Using a fiexible form of prodection function obtained from a Taylor-series expandon of a polynomial it is estimated that the labour productivity of the manefacturing sector is five per cent bigher with each dowbling of urban popalation. The sabotantial advantages to arban production seem to be at the beart of the arbaniantion procew that accompanied indantrialiantion in Greece. The policy implications are that decentralination policies may be fabifiable on regional equity bat not on economic efficiency grounds. Selection and promotion of a few urban centres in each region would be a more successful regional pollcy.

\section{Introduction}

It is widely believed that urban growth depends on scale economies in production known as 'agglomeration' economies (Richardson, 1978). They stem from

i) internal or large-scale effects and

ii) external effects arising from placing resources together in close spatial proximity. Firms in urban agglomerations experience productivity gains attributed to two types of external scale economies:

a) localisation economies, external to the firm but internal to each industry in a particular city. They reflect economies of intra-industry specialisation, labour market economies, communication benefits between firms etc.

b) urbanisation economies, external to both firms and industry and arising from the general level of economic activity internal to a city. They reflect benefits from a larger labour market and a larger service sector. In this case, only the size of the city, not its industry composition, affects the extent of scale economies relevant to a particular industry.

The existence of such economies induces increased productivity which leads in turn to higher wages and incomes that cause the existence and growth of cities. The size of cities is limited by consumption diseconomies such as commuting and housing cost increases and disamenities such as pollution, crime and social conflict. Both of them appear to be exponentially increasing with urban population (Henderson, 1983). Optimum city size is determined where the consumption costs outweigh the production benefits of population increase. As Mills (1972) argued, the formation of cities reflects market responses to opportunities for production and consumption.

Many recent articles have tried to determine and quantify the returns to scale in city size (Hoch, 1972; Sveikauskas, 1975; Segal, 1976; Nicholson, 1978; Moomaw, 1981; Henderson, 1982a). In all of them external economies of scale (localisation or urbanisation) were found to be very important in production. The respective elasticity was estimated to vary between 0.03 (Moomaw) and 0.10 (Henderson). The results are quite similar taking into consideration the differences in

i) data (manufacturing or economy-wide data for USA or Brazil),

ii) the production functions used for the estimations (Cobb-Douglas, CES, Taylor-series expansion) and

iii) the variables representing the different types of economies (urban population for urbanisation 
economies and urban employment in the particular industry a city specialises in for localisation economies).

This paper attempts an estimation of the role of agglomeration economies, assumed to be economies of urbanisation, in manufacturing production in Greece. Urbanisation is found to increase productivity significantly in a similar way as in USA or Brazil. Despite the weaknesses of our estimations due mainly to lack of available data, the similarity of production responses to urban growth in such different countries makes it difficult to deny the existence of returns to scale in city size (Gilbert, 1976). Thus, as Mera (1972-73) and Richardson (1976) have pointed out a decentralisation policy away from large urban centres seems to be justifiable on regional equity but not on economic efficiency grounds.

In section II of the paper we explain why agglomeration economies in Greece are due to urbanisation effects. Sections III and IV respectively present the production function to be estimated and the data available. In section $V$ we discuss the results of the estimations. Finally, section VI concludes the paper.

\section{Why urbanisation economies?}

Internal economies of scale in Greek manufacturing industry have been found to be unimportant (Nikolaou, 1978). Only few sectors such as cement and basic metals, which are resource oriented, respond positively to size. The reason for the nonsignificance of internal scale economies is attributed to the generally small size and low degree of specialisation of Greek firms (Nikolaou, 1978, pp. 168-71). Thus, external economies appear to be the main factor influencing locational preferences of firms in Greece.

If there were economies of localisation the spatial pattern of development would have been different from what it is. Specialisation of small or medium sized cities in the production of traded (exported out of the city) goods would be expected and these cities would be located close to raw materials sources. But this is not the Greek case at all. On the contrary, there is only one very large urban centre, Athens, which accounts for almost half of all economic activities taking place in the country. The second,
Salonika, although it accounts for only 10-15 per cent of all economic activities accounts for more than any of the remainder. Finally there are few other centres, much smaller than the first two, but showing signs of industrial activity. Taking into account the 'weak' structure of Greek industry expressed in small-scale, inward-looking, inefficient firms suffering from

i) a low degree of specialisation,

ii) limited vertical integration and

iii) high import independence,

(Giannitsis, 1983) we expect firms to be attracted by large market centres. Since the relevant choice in Greece was and still is restricted to a small number of options, firms locate preferably in Athens or Salonika, avoiding peripheral regions. Therefore, from the nature of industrial production and its geographic distribution we can make the assumption that external economies in Greece are caused by urbanisation effects. Consequently they can be measured by urban population or urban employment (Henderson, 1982b).

\section{The production function}

To quantify the effect of urbanisation economies at a specific time a 'cross-city' estimation of the production function of the manufacturing sector was needed. It was decided to use a flexible form which would avoid unnecessary restrictions and untested assumptions. Direct estimation of scale effects was also preferable. Following Henderson (1982a) the start was from a general form of production function

$$
Q=f_{1}(N) f_{2}(L, K)
$$

where $\mathrm{N}$ is urban population, $\mathrm{f}_{1}(\mathrm{~N})$ is a Hicksneutral external shift factor standing for urbanisation economies and $f_{2}(L, K)$ represents the firm's constant returns to scale technology. The 'parametric' external economies of scale notion introduced by Chipman (1970) is consistent with competitive equilibrium. A potential specification of $f_{1}(N)$ is $\mathrm{N}^{\theta}$ but various others were experimented with as well. Given the assumption of constant returns to scale (1) may be written as

$$
Q / L=f_{1}(N) f_{3}(k)
$$

where $k=K / L$. Taking logarithms, defining 
$\log \left[f_{3}(k)\right]=f[\log (k)]$ and taking a second order Taylor-series expansion (Chiang, 1974, p. 270) of $f[\log (k)]$ around $k=1$, i.e. $\log (k)=0$, we obtain a translog specification of (2)

$$
\begin{aligned}
& \log (Q / L)=A+\log \left[f_{1}(N)\right]+f^{\prime}(0) \log (k) \\
& +1 / 2 f^{\prime \prime}(0)[\log (k)]^{2}
\end{aligned}
$$

where $A$ is a constant. If $f_{1}(N)=N^{\theta}$ then

$$
\log \left[\mathrm{f}_{1}(\mathrm{~N})\right]=\theta \log (\mathrm{N})
$$

$\theta$ is an elasticity measure. Its interpretation is that a one per cent increase in urban population leads to a $\theta$ per cent increase in manufacturing output holding $\mathrm{K}$ and $\mathrm{L}$ fixed. Different urbanisation effects were experimented with, increasing at a rate which is declining with population, i.e. $f_{1}(N)=e^{\theta / N}$, or increasing with population, i.e. $f_{1}(N)=e^{\theta N}$. But $N^{\theta}$ gave the best results showing the highest explanatory power. Thus, the formulation $\mathrm{N}^{\theta}$ was adopted as the most suitable specification.

\section{Data}

In order to estimate (3) disaggregated data on manufacturing value added, labour, capital and population of the main urban centres of Greece were necessary. Since there are no such data referring to any other Greek city but the capital, Athens, it was necessary to use regional data covering 15-19 regions of Greece covering 1974-1977. Because of the small size of the country and its regions it was not unreasonable to assume that such data would be very similar to the data describing the major urban centre of each region since

i) manufacturing production is known to take place in urban rather than rural areas and

ii) most of these regions have only one major urban centre.

Data on Greek manufacturing production are published in the Annual Industrial Surveys. Separate data for the 20 sectors of manufacturing industry are given only for Athens and the rest of Greece as a whole. Thus, they could not be used for estimating different production functions for each sector. Data on large-scale ${ }^{1}$ manufacturing as one sector referring to value added and average annual employment in a regional breakdown are given for the years $1974-77 .{ }^{2}$ Unfortunately this disaggregation is not sufficiently detailed to give us a reasonable number of observations in order to estimate the production function for each of the four years separately. In 1974 there were only 15 observations which did not increase for the next two years until in 1977 there were 19 observations. Since there were not enough data to use them separately it was decided to pool them. Value added was defiated to 1970 constant prices. Dummy variables were also used for the last three years in case productivity changed in this period.

Information on capital presented problems as well. No complete capital data is published by any statistical service in Greece (Katsos, 1975; Yannopoulos, 1979; Kintis, 1982). The proxies used by these authors were either installed horsepower by industrial firms (existing only for the years 1973 and 1978 because it is published in the Industrial Census appearing every five years) or consumption of electricity for industrial use. These last data are published every year for the 51 regions in which Greece is administratively divided. The choice was very restricted. Finally it was thought that between the two alternatives it was consumption of electricity for industrial use that had more advantages, at least as far as the detailed information was concerned. Therefore, it was used as a proxy for capital in the estimation of the production function.

Urban population was needed for the years 1974-77 disaggregated into the regions for which production data were available. Population Censuses in Greece are published every ten years, the two last ones being 1971 and 1981. Thus, it was necessary to interpolate urban population by administrative region and add them up to the regional level required by the rest of the data. ${ }^{3}$

Although the production function of the manufacturing sector (and of most of its 2-digit subsectors) has already been found to be homogeneous of

\footnotetext{
${ }^{1}$ The data concern only large-scale manufacturing, i.e. firms with more than 20 employees. In 1977 they represent 75 per cent of value added in the manufacturing sector.

${ }^{2}$ Recently the 1980 Annual Industrial Survey has been published but because of the three-year gap (1977-80) and the differences in the regional breakdown used it was decided not to take the more recent data into account for estimation purposes.

${ }^{3}$ Data on value added, consumption of electricity for industrial use, employment and number of firms are published in the Annual Industrial Surveys 1974-77. Data on urban population are taken from the Population Censuses of 1971 and 1981 . All of them are published by the National Statistical Service of Greece.
} 
Table 1

Production function estimation results*

\begin{tabular}{|c|c|c|c|c|c|c|c|}
\hline Dep. var. & $\mathrm{Q} / \mathrm{L}$ & $\mathrm{Q} / \mathrm{L}$ & $Q / L$ & $\mathrm{Q} / \mathrm{L}$ & $\mathrm{Q} / \mathrm{L}$ & $Q / L$ & $Q / L$ \\
\hline \multicolumn{8}{|l|}{ indep. var. } \\
\hline Constant & $\begin{array}{c}2.21 \\
(5.05)\end{array}$ & $\begin{array}{c}2.24 \\
(5.00)\end{array}$ & $\begin{array}{c}3.88 \\
(11.72)\end{array}$ & $\begin{array}{c}2.92 \\
(8.40)\end{array}$ & $\begin{array}{c}2.90 \\
(8.54)\end{array}$ & $\begin{array}{c}2.63 \\
(5.05)\end{array}$ & $\begin{array}{c}2.61 \\
(5.14)\end{array}$ \\
\hline $\mathrm{K} / \mathrm{L}$ & $\begin{array}{c}0.21 \\
(7.88)\end{array}$ & $\begin{array}{c}0.21 \\
(7.73)\end{array}$ & $\begin{array}{c}0.25 \\
(8.11)\end{array}$ & $\begin{array}{c}0.19 \\
(7.13)\end{array}$ & $\begin{array}{c}0.19 \\
(7.25)\end{array}$ & $\begin{array}{r}-0.06 \\
(0.30)\end{array}$ & $\begin{array}{r}-0.06 \\
(0.32)\end{array}$ \\
\hline $\mathbf{N}$ & $\begin{array}{c}0.05 \\
(2.37)\end{array}$ & $\begin{array}{c}0.05 \\
(2.29)\end{array}$ & $\begin{array}{c}0.04 \\
(1.74)\end{array}$ & - & - & $\begin{array}{c}0.05 \\
(2.51)\end{array}$ & $\begin{array}{c}0.05 \\
(2.59)\end{array}$ \\
\hline$S$ & $\begin{array}{c}0.39 \\
(4.96)\end{array}$ & $\begin{array}{c}0.39 \\
(4.80)\end{array}$ & - & $\begin{array}{c}0.38 \\
(4.51)\end{array}$ & $\begin{array}{c}0.38 \\
(4.64)\end{array}$ & $\begin{array}{c}0.39 \\
(4.85)\end{array}$ & $\begin{array}{c}0.39 \\
(5.04)\end{array}$ \\
\hline D75 & - & $\begin{array}{c}0.01 \\
(019)\end{array}$ & - & $\begin{array}{r}-0.03 \\
(0.49)\end{array}$ & - & $\begin{array}{r}-0.03 \\
(0.54)\end{array}$ & - \\
\hline D76 & - & $\begin{array}{c}-0.02 \\
(0.36)\end{array}$ & - & $\begin{array}{c}0.16 \\
(0.23)\end{array}$ & - & $\begin{array}{c}0.16 \\
(0.24)\end{array}$ & - \\
\hline D77 & - & $\begin{array}{c}0.04 \\
(0.60)\end{array}$ & - & $\begin{array}{c}-0.36 \\
(0.54)\end{array}$ & - & $\begin{array}{c}-0.51 \\
(0.08)\end{array}$ & - \\
\hline$(K / L)^{2}$ & - & - & - & - & - & $\begin{array}{c}0.07 \\
(1.43)\end{array}$ & $\begin{array}{c}0.07 \\
(1.50)\end{array}$ \\
\hline $\mathrm{R}^{2}$ & 0.65 & 0.63 & 0.51 & 0.60 & 0.62 & 0.64 & 0.65 \\
\hline SER & 0.17 & 0.18 & 0.20 & 0.19 & 0.18 & 0.18 & 0.17 \\
\hline
\end{tabular}

* The functions are estimated by OLS. Their general form is

$\log (\mathrm{Q} / \mathrm{L})=\beta_{0}+\beta_{1} \log (\mathrm{K} / \mathrm{L})+\beta_{2} \frac{1}{2}[\log (\mathrm{K} / \mathrm{L})]^{2}+\beta_{3} \log (\mathrm{N})$

$+\beta_{4} \log (\mathrm{S})+\beta_{5} \mathrm{D}_{75}+\beta_{6} \mathrm{D}_{76}+\beta_{7} \mathrm{D}_{77}$

$t$-ratios are shown in parentheses.

The estimation adopted is the one shown in the first column.

degree one (Nikolaou, 1978), it was decided to test for degrees of homogeneity different from one. ${ }^{4}$ Consequently the average firm size $(S=$ number of employees/number of firms) in each region was controlled.

\section{Results}

Following the discussion of the properties required by the equation estimating the production function and of the problems caused by the lack of available data, we finally estimated

$$
\begin{aligned}
\log (\mathrm{Q} / \mathrm{L})= & \beta_{0}+\beta_{1} \log (\mathrm{k})+\beta_{2} \frac{1}{2}[\log (\mathrm{k})]^{2} \\
& +\beta_{3} \log (\mathrm{N})+\beta_{4} \log (\mathrm{S})+\beta_{5} \mathrm{D}_{75} \\
& +\beta_{6} \mathrm{D}_{76}+\beta_{7} \mathrm{D}_{77}
\end{aligned}
$$

where $D$ is a dummy variable taking the value of 1 in the year it refers to and 0 in all other years. The results are shown in Table 1.

All the dummies were found to be insignificant indicating no significant exogenous change in manufacturing productivity in the 1974-77 period. Inclusion of both $\log (k)$ and $[\log (k)]^{2}$ in the equation rendered both $\beta_{1}$ and $\beta_{2}$ insignificant (giving $\beta_{1}$ a negative sign!). Inclusion of the quadratic term did not alter any of the estimates. Thus, it was to leave $[\log (k)]^{2}$ and the dummies out. $\mathrm{R}^{2}$ increased from 0.64 to 0.65 by dropping these variables.

Urbanisation effects as estimated by $\beta_{3}$ seem to be very important. $\theta=0.05$ means that if urban population increases by ten per cent in any of the regions, $\mathrm{Q} / \mathrm{L}$ (productivity) will increase by 0.5 per cent without any change in inputs. Or a ten per cent increase in urban population will allow wages in manufacturing to increase by $(0.5 \alpha)$ per cent, where

\footnotetext{
${ }^{4}$ We would also like to control for differences in the quality of labour force but data on the education of economically active population by region are available only for 1971 . Since data on 1981 have not been published yet it was not possible to interpolate the educated active population in 1974-77, years for which the manufacturing production function is estimated. There are similar studies, though, where the effect of education on productivity was also estimated and was found to be weak (Besen, 1968; Sveikauskas, 1975) or non-significant (Segal, 1976; Henderson, 1982a).
} 
$\alpha$ is labour's share in production holding output prices and capital fixed. It is interesting to notice the similarity in sign and size of our results with those of other relevant studies referring to countries so different to Greece as USA and Brazil. ${ }^{5}$

The significant positive effect of average firm size was rather a surprise, since a detailed study by Nikolaou (1978) has shown that internal economies of scale in Greek manufacturing industry are not important. If we accept her results, $S$ must be catching some other effect. A composition effect seems to be possible. ${ }^{6}$ Different industries having different optimal sizes and productivities may grow in different cities, i.e. an individual city may specialise in especially productive or unproductive sectors. Even the same (2-digit) sector may be cormposed of different (3- or 4-digit) subsectors ${ }^{7}$ having different optimal sizes and being more or less productive. Since our data do not distinguish between different sectors but examine manufacturing industry as a whole, the effect caught by $\mathrm{S}$ may be a composition effect relevant to each city's specific industry. The more aggregate the data the higher the composition effect is likely to be. If we had separate information for each sector or subsector of manufacturing industry, it would be possible to distinguish between the composition effect and any real average firm size effect. Consequently, taking into consideration the very aggregate data used, ${ }^{8}$ it seems plausible to assume that $S$ picks up a composition and not an internal scale effect. To capture and control this effect even through $S$ is useful in measuring more accurately urbanisation economies.

\section{Conclusions}

Urbanisation economies have been found to play a significant role in the productivity of manufacturing industry in Greece. Their size justifies the strong tendency exhibited by Greek firms to locate in large urban centres, and to show overwhelming preference for Athens, (of course all 20 sectors of manufacturing need not show the same response to urbanisation) (Louri, 1985). The more marketoriented the sector the greater the influence of city size on its production will be. The reverse should hold for resource oriented sectors. ${ }^{9}$

Observed concentrations of population and economic activities in large agglomerations, despite much discussion of urban 'discomfort and inconvenience', can be explained by our results. Higher incomes are feasible in larger cities because productivity is higher: on average, labour productivity is five per cent higher with each doubling of urban population. The substantial productivity advantages of urban production must be at the heart of the urbanisation process that has accompanied industrialisation in Greece. The modern economy in Greece, as in other developed or developing countries, has sound reasons to be an urban economy.

The policy implications of the results here are that decentralisation policies, so much favoured in Greece, can be pursued on the grounds of regional equity, but not on the grounds of economic efficiency. Efficiency dictates that firms prefer large urban locations and so the persistent failure of decentralisation policies is now easily understood. Selection of a few major centres and promotion of their attractiveness by providing more infrastructure, for example, would bring about better results than the "egalitarian"10 policies followed up to now, and a regional policy complying with the demands of economic efficiency would have a better chance of success.

\footnotetext{
${ }^{5}$ An external economies effect (localisation in this case) approximatley equal to 0.10 has been estimated by Henderson (1982a) using 1970 data for Brazil. In the same study the respective effect for USA using 1970 data was estimated to vary between 0.02 and 0.10 depending on the sector. Sveikauskas (1975) has estimated an urbanisation effect of 0.06 using 1967 US data. Segal (1976) has estimated a similar effect (0.08) using 1967 data for the entire US urban economy. Moomaw (1981) revised both estimates downwards. Using more accurate data he estimated an urbanisation effect of 0.03 .

- A similar composition effect has been found by Henderson (1982a) for Brazil and Sveikauskas (1975) for USA.

${ }^{7}$ E.g. clothing or furniture can be quite different goods belonging to different subsectors if they come from large-factory standardised or small-scale specialised production processes.

8 Data on aggregate manufacturing production including 20 different 2-digit sectors was used.

${ }^{9}$ Louri (1985) found that consumer goods producing sectors such as furniture, apparel, printing etc. exhibited much higher responses to urbanisation economies than intermediate or capital goods producing sectors such as non-metallic minerals, machinery, metal products etc. The responses estimated by her refer to the investment decisions of the 20 manufacturing sectors and not their production functions. The data used for these estimations are different than the data used in this study, but the results support each other strongly. 10 'Egalitarian' in the sense that they favoured all parts of a region equally. Urban centres with higher development potential within a region were not treated differently.
} 


\section{REFERENCES}

BESEN, S. M. (1968). 'Education and productivity in US manufacturing: Some cross-section evidence', Journal of Political Economy, Vol. 76, pp. 494-497.

Chisng, A. C. (1974). Fundamental methods of mathematical economics. McGraw-Hill Kogakusha Ltd.

Chipman, J. (1970). 'External economies of scale and competitive equilibrium', Quarterly Journal of Economics, Vol. 84, pp. 347-385.

GinNnitsis, T. (1983). The Greek industry: development and crisis. Athens: Gutenberg.

GILBERT, A. (1976). 'The arguments for very large cities reconsidered', Urban Studies, Vol. 13, pp. 27-34.

HENDERSON, J. V. (1982a). 'Efficiency of resource usage and city size', Brown University Working Paper, No. 82-14.

Henderson, J. V. (1982b). 'The impact of government policies on urban concentration', Journal of Urban Economics, Vol. 12, pp. 280-303.

HENDERSON, J v. (1983). 'Industrial bases and city sizes', American Economic Review Papers and Proceedings, Vol. 73, No. 2, pp. 164-168.

Hосн, I. (1972). 'Income and city size', Urban Studies, Vol. 9, pp. 299-328.

KATSOS, G. (1975). An evaluation of the siructure of protection in Greece during the post-war years, Ph.D. Thesis, University of Lancaster.

KINTIS, A. (1982). The development of Greek industry. Athens: Gutenberg.

LOURI, H. (1985). Regional policy and investment in Greek manufacturing industry: 1971-1982, Ph.D. Thesis, University of Oxford.
MERA, K. (1972-73). 'On the urban agglomeration and economic efficiency', Economic Development and Cultural Change, Vol. 21, pp. 309-324.

MiLLS, E. S. (1972). Urban Economics. London: Scott, Foresman and Co.

Moomaw, R. L. (1981). 'Productivity and city size: a critique of the evidence', Quarterly Journal of Economics, Vol. 96. pp. 675-688.

National Statistical Service of Greece, Statistical Yearbook, Annual issues 1972-1982. Athens.

National Statistical Service of Greece, Annual Industrial Surveys, Annual Issues 1973-1977. Athens.

Nicholson, N. (1978). 'Differences in industrial production efficiency between urban and rural markets', Urban Studies, Vol. 15: pp. 91-95.

NixOLAOU, K. (1978). Inter-size efficiency differentials in Greek manufacturing industry. Athens: KEPE, Special Studies Series, No. 7.

RichardSON, H. W. (1976). 'The argument for very large cities reconsidered: a comment, Urban Studies, Vol. 13, pp. 307-310.

RICHARDSON, H. W. (1978). Regional and urban economics. Harmondsworth: Penguin.

SEgal, D. (1976). 'Are there returns to scale in city size?', Review of Economics and Slatistics, Vol. 58, pp. 339-350.

SveikausKas, L. (1975). 'The productivity of cities', Quarterly' Journal of Economics, Vol. 89, pp. 393-413.

YANNOPOULOS, G. (1979). 'The effects of full membership on the manufacturing industries', in L. Tsoukalis, (ed.), Greece and the European Community. Westmead: Saxon House.. 